\title{
ARTICLES
}

\section{Revisiting the Archival Finding Aid}

\author{
Richard J. Cox
}

\begin{abstract}
Archivists have been creating finding aids for generations, and in the last three decades they have done this work via a succession of standardized formats. However, like many other disciplines, they have carried out such work in violation of systems analysis. Although purporting to have the users of finding aids systems first and foremost in their mind, archivists have carried out their descriptive work apart from and with little knowledge of how researchers find and use archival sources. In this article, questions are raised about the utility of archival finding aids and how they will stand the test of time. Indeed, archivists, purportedly concerned with considering how records function and will be used over time, ought to apply the same kind of analysis and thinking to their finding aids. In this article, we explore three ways archival finding aids might be examined by outsiders, namely, those concerned with museum exhibitions, design experts, and accountability advocates. Doing this should assist archivists to reevaluate their next wave of experimentation with descriptive standards and the construction of finding aids. Archivists should expand the notion of what we are representing in archival representation.
\end{abstract}

Richard J. Cox, MA, PhD, is Professor, Archival Studies, and Chair, Library and Information Science Program, University of Pittsburgh School of Information Sciences (E-mail: rcox@mail.sis.pitt.edu).

Journal of Archival Organization, Vol. 5(4), 2007

Available online at http://JAO.haworthpress.com

(c) 2007 by The Haworth Press. All rights reserved.

doi: $10.1080 / 15332740802153245$ 
KEYWORDS. Accountability, archival representation, arrangement and description, descriptive standards, design, EAD, finding aids, museum exhibitions, post-modernism, US MARC AMC, user studies, World Wide Web

\section{INTRODUCTION: REMEMBRANCE OF THINGS PAST}

When I entered the archival profession in the early 1970s, there was little discussion about descriptive standards. I remember a conference in 1973 in which an experienced archivist mused about archival arrangement and description in the most idiosyncratic fashion possible. Each institution had its own traditions, practices, and approaches, and it seemed acceptable and logical that unique manuscripts and archival records would be handled in unique ways from institution to institution. The key, after all, was the archivist's knowledge. Researchers, generally assumed then to be historians, would also possess immense knowledge about their own field and provide additional context that would be extremely useful in their negotiations with the archivist and in identifying just what records they needed to consult.

I also remember being troubled then by some of the very loose practices. Most of what bothered me I dealt with by developing consistency in how we did things in my own institution, and that seemed to be challenge enough. My first employer was a 130-year-old private historical society, so bringing consistent descriptive practice to it was difficult enough. There, you could discern particular periods when an individual stamped his own sense of how to do things, and you learned quickly by understanding when a particular finding aid (of every conceivable variety) was done and who was responsible for it. We hired a librarian to work with us in bringing consistency to our internal indexing terminology. Of course, this was happening in the days when we relied on an ink-dribbling, hand-rolled stenciling device, so the extent of what damage we could do in archival descriptive practice was quite limited. Even with such efforts, I found myself writing a master guide to finding aids both for staff and researchers, trying to describe the potpourri of various articles, books, card catalogs, loose-leaf binders, and other devices that had been accumulated since the first guide had been published in 1854. When one came across a description reading "located near water bucket in basement," no one panicked; all you did was check to make sure that the box of records was not still there (they were not, but the century-old water bucket was). 
Today we seem to be in the golden age of archival descriptive standards. Almost thirty years ago, archivists sought to standardize inventories and registers that had been used by the National Archives and the Library of Congress since the 1940s, bringing some order to the kinds of internal finding aids researchers could expect to find (only a small number of archival repositories seemed to publish these kinds of finding aids - and for good reason-since they were more likely to be used by archivists than researchers). Twenty years ago, the US MARC AMC format forced archivists to learn, use, and adapt standardized indexing, a thesaurus, and other methods long used by librarians and other information professionals in order to place their descriptions in automated library catalogs and national and international bibliographic utilities. A decade ago the emergence of encoded archival description (EAD) brought the promises of standardizing finding aids for use on the World Wide Web, supplementing the MARC records, so the riches of archival holdings could be more easily discovered.

\section{GENERATIONS OF DESCRIPTIVE PRACTICE}

Little more than a decade after its emergence, the newest version of archival descriptive standards-EAD — reigns supreme, but reveals some stresses and strains. Each successive generation of standards supporting the production of finding aids, from the formulation of the structure of manuscript registers and archival inventories in the mid-twentieth century to the adoption of the tags and fields of MARC-based records to the reformulation of hypermedia versions of registers and inventories in EAD, has met with quick acceptance. Nevertheless, as with nearly all developments in the standardization of archival description, there have been reservations, from costs and techniques to the implications for users, expressed about the utility of every other descriptive genre. As with every stage of development in archival description, we have moved forward with modest knowledge of the use of archival materials (in the case of EAD, we have little information about users' experiences with online finding aids). ${ }^{1}$ Still, experts like Helen Tibbo refer to the "rise of a ubiquitous networked information environment" as a revolution changing "perspective, policy, and practice" in archival description, ${ }^{2}$ and studies are emerging suggesting that historians and other heavy users of archival sources are developing new expectations for how they access archives in the Web age. ${ }^{3}$ Perhaps the entire past half-century of developments in archival description represents 
a revolution of sorts, but one that archivists are far too closely involved with to understand or evaluate objectively.

Archivists have tended to prepare their finding aids in a language and manner they are more comfortable with than are the researchers seeking to use archives, ${ }^{4}$ and they maintain the same content and format of the finding aids even as they have learned that researchers and their expectations are changing. ${ }^{5}$ A new generation of researchers have begun to make statements such as: "A knowledge of what elements people use to describe their information need and how they structure their requests will make it possible to design better research aids, including automated information retrieval systems, finding aids, and web interfaces, that will guide the user to the information she or he wants"6; this represents a sea change of thinking about the nature and construction of archival finding aids. It is why institutions adopting EAD may believe that they have created better and more effective finding aids, but that in reality most of the implications of utilizing this latest archival descriptive approach are unknown because archivists have not acquired the depth of needed knowledge about how their researchers use or desire to use documentary sources. ${ }^{7}$ It is also why some archivists using descriptive standards have determined the need to circumvent accepted rules to serve better particular kinds of researchers. ${ }^{8}$ Archivists still have a long way to go in determining how researchers are actually successful in archives, although there are efforts underway to gain a better understanding of this; indeed, some are now openly assessing the means by which to study the ways archival sources and finding aids are used, such as evaluating the prospects of having these researchers maintain diaries for later evaluation. ${ }^{9}$

\section{STUDYING USERS AND FINDING AIDS}

Studies about archival users have been illuminating about the effectiveness of archival finding aids. One suggests that a characteristic of the successful archival researcher is knowledge of archives, what they term "archival intelligence," indicating the role archivists must play in educating their researchers. This study notes that finding aids are not well understood, nor for that matter, are other access tools to archival records. ${ }^{10}$ Another study indicates that despite evidence that researchers like historians are using online finding aids, archivists cannot assume that archival resources are more widely available. Helen Tibbo, in this analysis, notes that historians also rely just as much and more in many cases 
on traditional older aids, concluding that the "message for libraries and archives is clear. They must maintain access to traditional means of locating resources while building easily navigable websites that contain useful information." 11

While some make suggestions for more rigorous archival user education, it is also just as true that the way archivists prepare finding aids ought to be reexamined as well. In the latter study, Tibbo comments that many historians don't know about the online finding aids, and she advocates the need for better publicity: "To accomplish this, repositories must move beyond provision of access and bibliographic instruction. Time and other resources must be allocated to user studies, user education, and especially, outreach within repository budgets. These should not be seen as dispensable add-ons. This is the business of the archival enterprise in the digital age."12 However, it is just as much the case that archival finding aids, the traditional printed ones and the newer online versions, have not been understood by researchers. Perhaps the real business of postmodern archival enterprise ought to be re-evaluating just what finding aids represent over time, studying them as a documentary source reflecting attitudes and practices of the archival community at various times. At the least, archivists need to recognize that, as Wendy Duff and Catherine Johnson state, "finding information in archives is not an easy task" and that "designing intuitive systems that meet the researchers' needs requires a thorough understanding of the information-seeking behavior of archival users." "13

Occasionally, some archivists, such as Michelle Light and Tom Hyry, have made more radical pronouncements about archival finding aids. Although acknowledging that finding aids have generally performed an excellent service, especially in providing "important contextual information" about records and in representing the "cohesive nature of records in a collection or record group," 14 they detect some problems. They think that finding aids "fall short" because they omit some "contextual information," namely, the "impact of the processor's work" on bringing order and coherence to the records and in disguising that the finding aid represents "but one viewpoint of a collection." 15 Light and Hyry provide a postmodern spin to their analysis, suggesting that traditional archival finding aids are modernist in their "ways of understanding order and truth."16 From my vantage you don't need to become so tangled up in philosophical and theoretical perspectives to detect such problems; good old-fashioned common sense suffices. These archivists argue that more information about the collections, such as their acquisition, needs to be made public, and more importantly, that we need to construct our online 
finding aids in a manner that allows others to submit annotations about the documents, their use, and the value of the finding aids.

More issues about finding aids persist, even considering that the motivations for developing EAD were as pure as they come. Encoded archival description was hatched because it was a means to make information about archival materials widely available on the Web, providing easy (maybe nearly instantaneous) access. What studies about this have done is suggest that this objective has been more a dream than a realization. ${ }^{17}$ As one of the pioneers of the EAD approach suggests, EAD was intended to overcome the limitations of earlier archival descriptive standards, such as MARC AMC, where the "generalized descriptions found in AMC records can only lead a researcher to a collection which may have individual relevant items" and where the descriptions are not the full information found in traditional archival finding aids. ${ }^{18}$ Few would argue about such aspirations.

Indeed, we seem now to have an ever-shifting target. The greater the possibilities for individuals using the Web for online archival research, the greater the changes may result in how archivists provide assistance to their researchers-if for no other reason than that researchers may feel less need to come in-person to the archives. ${ }^{19}$ Yet, this may have more to do with other issues than just technological changes. At various critical junctures in the development of archival descriptive standards, we have tended to focus on technical and process issues rather than in creating mechanisms to help researchers. Some of this may suggest a faith about or over-confidence in archivists' sensitivity to what researchers need, or and maybe more important, it might imply an interest in the arrangement and description function that supersedes the end goal of enabling researchers to discover what they are looking for. ${ }^{20}$

Twenty years ago, Lawrence Dowler noted that it is difficult, among other things, to determine how to shape archival finding aids to meet user needs because we then knew so little about how researchers used archival records, laying out a research agenda to address this professional lacunae. ${ }^{21}$ Dowler's essay was part of a flurry of reconceptualizing the notion of archival use at that time which has finally begun to pay off with new studies on how archival documentation is used with more specific notions about how any type of finding aid or guide is used. ${ }^{22}$ As Jacqueline Goggin wrote two decades ago, "only recently have archivists begun to acknowledge the deficiencies in current archival administrative practices and to argue that they should pay more attention to the users of archival materials." ${ }^{23}$ While we could restate this sentiment today, we can at least acknowledge that we know a lot more about the users of archival materials. ${ }^{24}$ 
At every transitional stage between new modes of finding aids, we seem to learn something about the nature and limitations of these devices. Dennis Meissner, in evaluating the process of transforming traditional archival finding aids into EAD finding aids, notes that the problems that they found were not because these finding aids "were poorly written, or inaccurate, or that their descriptions of collections were incomplete. Rather, the problems lay in the way that they structured, ordered, and presented information. The effect of these problems in frustrating access to collections would be magnified tremendously when the finding aids were delivered over the web, with no hope of explanation by a staff member." 25 This statement was a reminder that the purpose of EAD finding aids was to take advantage of new computer software and hardware, as well as the availability of the Internet. It is also a remainder that if we discern such problems, what must our research clientele think of these aids?

Archivists have been trying to analyze the use of their finding aids and users' habits in general in order to possess a better understanding of what they need to do in descriptive work. Christopher Prom, in a study about the usefulness of online finding aids, indicates the challenge confronting archival representation: "The representation of archival materials is inherently complex, and researchers' successes in locating materials sometimes seem to show a high dependence on 'strange attractors' or clusters of information that do not at first appear to be logically connected." 26 Acknowledging the great attention devoted to finding aids, descriptive standards, and understanding users' activities, Prom's study reveals that online finding aids are "most efficiently used by either archival and computer experts," 27 a conclusion suggesting to me the need to rethink what we are doing with finding aids (although Prom believes that archivists need to focus on gaining a "deeper understanding of users"). ${ }^{28}$ Prom suggests, instead that the focus remains on the archivist as access mediator, whether the reference process is on the in-person or online reference function. We might ask if the reliance on the archivist as mediator, as a living finding aid, is not also an indictment of the usefulness of our traditional and newer (but really not all that newer in scope and content) finding aids (although in certain situations, such as administrative use of archival records, this might have more to do with the needs of the parent organizations and even their confidence in the archivists working there). ${ }^{29}$

When examining an archival function such as the construction of finding aids and the necessity of descriptive standards, it is often easy to be unfairly critical of present efforts or the recent past. We need to be able to step outside of our own institutional and disciplinary surroundings and 
reevaluate where we are, where we are heading, and where we should be. From time to time, outsiders to the archival community have looked at what archivists have been doing in certain activities. Historian William C. Binkley, four decades ago, provided a critical assessment of the first three published volumes of the National Union Catalog of Manuscript Collections, concluding that they "constitute the most important step ever taken in this country toward providing concisely and in conveniently available form the basic description and the information most essential to a research worker who is surveying the field and deciding where his source material is most likely to be found." ${ }^{30}$ Such efforts are necessary, especially since we have long possessed evidence that archival descriptive efforts have not been often clear to those who we think will use the finding aids as a mean of getting into the archival sources. ${ }^{31}$ We also need this external perspective since archivists, looking at themselves and their work, tend to see the finding aids in extremely positive terms. A quarter of a century ago, Mary Jo Pugh writes, "Archivists tend to be too passive and bureaucratic when writing inventories and registers. Inventories, which should be the major intellectual accomplishment of our profession, are too often merely lists of container and file headings." 32 Yet, many archivists continue to point to finding aids as their main priority and their preeminent contribution to scholarship.

I believe one might be hard-pressed to sustain an argument that most finding aids are an intellectual accomplishment. In this article, I explore three ways archival finding aids might be examined from outside our own professional community. Ultimately, they might be evaluated like museum exhibitions have been by historians, anthropologists, and other scholars, as artifacts defining their particular view of the world. Or, archival finding aids can be studied by those who are experts on design, considering the message they intend to convey to society. And finally, archival finding aids might be one other means by which archivists are, or could be, held accountable to society. Such perspectives take us far from the burgeoning new scholarship on how individuals find and use archival sources, a new set of research that will provide a much fresher and more balanced view of the purpose and utility of archival finding aids. These are not the only ways we can look at finding aids, but they are a start in stepping outside archival boundaries (getting researchers feedback is another way of breaking through the boundaries).

Archivists and their colleagues have predicted great breakthroughs in archival representation for many years. David Bearman, considering the AMC format two decades ago, argued that the "challenge of the next 
century will be to transform archives from repositories to intermediaries. Archivists must ask how they can best position their institution to deliver information in all its richness to the citizens of tomorrow who may learn from, and work with, archives as a primary cultural resource. Information delivery begins with the reexamination of finding tools and access points, but it doesn't end until the information itself is provided directly to patrons, in their own intellectual framework, on their own terms, and wherever they may be." ${ }^{33}$ Such pronouncements have galvanized considerable discussion, but they have not necessarily transformed what archivists are actually doing with their finding aids and the provision of access to their holdings. Maybe the problem is that we have not used our imaginations enough to squint into the distance in order to imagine how others see us and our finding aids.

We are learning more, however, as specific research is completed about the use of archives. Elizabeth Yakel, studying how users view archives and archivists in their research process, learned that "users' conceptions of archival access tools varied greatly" and if nothing else, were substantially different from how archivists thought they might see them. ${ }^{34}$ Yakel learned what others had learned, that researchers did not rely on archival finding aids but, instead, used "word of mouth" as well as citations in other studies. ${ }^{35}$ Yakel relied on interviews with researchers, and then transformed this into practical advice for educating users, built around finding aids. Yakel writes:

It is in finding aids that users' representations of archives meet archivists' representations of collections. If these two cognitive representations intersect enough, the user is able to locate and utilize the archives and to identify primary sources that may hold the answers to his or her inquiry. If these representations diverge, the access tools are useless for the researcher. Creating finding aids that are true boundary objects is key. Researcher after researcher noted the intricacies of access systems and it is apparent that finding aids are not the transparent tools for users that archivists intend. ${ }^{36}$

While Yakel works in the here and now, dealing with current researchers, my predilection is to take a longitudinal and maybe impractical, but potentially illuminating, perspective. By seeing how other representational devices, such as museum exhibitions, have changed over time, we can adopt a more realistic notion of the value of similar devices, such as the archival finding aid, in our field and time. If there is any practical value in 
this, it is in adopting a greater openness for how others see us and, perhaps, shifting our activities to serve posterity rather than our own perceptions of the present, or in seeking to find some kind of "archivally" pure mindset that enables archivists to set themselves apart from others. ${ }^{37}$

I hope this article adds to the small, but important, reflective literature on archival description. Archivists have been so intent on building new and better systems to assist researchers in finding the documentary sources they need, that they only occasionally pause to be reflective about the progress made or in discerning what they may have learned. For a couple of generations, archivists rushed ahead of researchers, neglecting to study how researchers operate, in designing and building descriptive systems. And when we have paused, sometimes our observations have been sobering. More than a decade ago, Ann Pederson observed that "we have not succeeded in unlocking the full value of archival resources," suggesting major limitations with our finding aids and descriptive standards. ${ }^{38}$ When will we fulfill this dream?

\section{LEARNING FROM MUSEUM SCHOLARSHIP}

If we think of an archival finding aid as a form of exhibition, then we might wonder just why these guides (published and unpublished) do not ever become controversial. Thinking about the history and nature of museum exhibitions causes us to stop thinking how innocent any organization of exhibitions might be and instead to understand how they reflect present ideas and biases. The situation has intensified in the past decade. Steven C. Dubin notes:

Museums and their exhibitions have become controversial sites in a number of respects over the past few years. They no longer merely provide a pleasant refuge from ordinary life, nor are they simply repositories of received wisdom. Museums have moved to the forefront in struggles over representation and over the chronicling, revising, and displaying of the past. Museums today differ greatly from their predecessors. ${ }^{39}$

Archives, at least in their major function of representing records through finding aids, have been spared such problems. One might wonder if this will change as they build a more pronounced presence on the World Wide Web. Or, is it because archival finding aids really are not read or engaged 
in any way that is similar to what happens with museum exhibitions (and their catalogs)?

We might think of the archival finding aid as being like the museum display case. Kevin Walsh provides a useful description of the display case:

The developing ability to place objects in ordered contexts often implied a unilinear development of progress. Such representations implied a control over the past through an emphasis on the linear, didactic narrative, supported by the use of the object, which had been appropriated and placed in an artificial context of the curator's choosing. This type of display is closed, and cannot be questioned. ... In a way, museums attempt to 'freeze' time, and almost permit the visitor to stand back and consider 'the past before them.' This is the power of the gaze, an ability to observe, name and order, and thus control. $^{40}$

In the same fashion, archivists freeze time and add control in their description of a records system. In many ways the closing and ordering is more intensive in the archival version, as descriptive standards and traditions in the finding aid have often shifted more with an eye on the archivist than on the use of the archives.

Thinking of the finding aid as being like the museum exhibition, in the latter's traditional or historic role extending order and coherence to the world, also opens up the sense of connecting the archival finding aid to the real world. Chon A. Norriega has commented on the changes wrought by the American museum's need to attract more funding support from the public:

The result has been a drastic change in the way museums approach their audience. Rather than edifying, the museum increasingly plays to the masses in competition with tourist sites, amusement parks, cultural centers, bookstores, and shopping malls. As such, the museum exhibition has become much more event-oriented-in roughly the same way as motion pictures during this period-while the museum itself now offers a wide range of revenue-generating services and activities beyond that of the exhibition proper. $^{41}$

One might dismiss any relevance of this to the archival finding aid since the museum exhibition is much more a public device. Yet, the finding aid 
is intended if not to attract researchers, than at least to edify them in a manner that helps them to use the archives. We can go further, however, in realizing that the archival finding aid also competes with entities such as the World Wide Web in providing or offering information (or better yet, evidence).

Writing effective finding aids is a complicated business, one that often has been blotted from existence by the pragmatic desire to train archivists to be able to produce utilitarian guides to their records. We know that the holdings of an archives possess layers like one finds in an archaeological dig. Paul Collins notes, "To see any library, any bookstore, any archive, is like seeing a city: you are viewing buildings constructed atop the unknown and unknowable cities that once were and once might have been." ${ }^{2}$ It is why "discoveries" are always being made in repositories like archives. No matter how complex archival finding aids might become, it seems unlikely that they can represent effectively all the layers, details, nuances, and vagaries that constitute records. To try to achieve the full richness of an archival repository would be to have the ability to see the full text of every document, and while some futurists strive to achieve this objective, it seems unlikely that it will ever happen given the quantity of records, the number of archivists, and the resources available to archivists.

The preparation of archival finding aids also partially transforms the records. Archivists, as they work on describing records, are generally not working with full sets of documents but rather they are examining records already appraised (formally or informally). What archivists sometimes neglect to consider is how they transform the records as they examine them and transform them again as they describe them. Charles Merewether, considering ruins, brought up an 1896 discussion of ruins by Freud who wondered if they should be left as is or excavated, concluding that ruins cannot be left as is because they speak. According to Merewether, Freud "concluded that only by digging into the rubble does one reveal the fragments of a larger story or meaning. Yet, when ruins are uncovered they are irrevocably changed: they become part of the present." ${ }^{, 43}$ It is not hard to imagine archival records as ruins, as they are often survivals with all the marks of time's passage; even digital archives can be viewed in this way as they have perhaps faced an even more daunting task of survival, having gone through all the vagaries of hardware and software transformations.

One wonders what archival finding aids are saying to researchers, if language communicates and, as some argue, records speak. Of course, all objects, records included, have language attributed to them, or as Miguel Tamen argues, "the very idea of an object's performing an action is already 
quite extraordinary. And yet, to speak of talking corporations, communicating lawns, scheming statues and moving icons makes a certain sense, at least in some well-defined contexts." ${ }^{4}$ What would be the best context for the archival finding aids? Certainly, finding aids, dating back in the modern sense to the nineteenth century, first existed in print form, then in online catalogs, and more recently on the World Wide Web, and it is the Web that provides the best opportunity for finding aids to speak (literally and figuratively). But, as I have argued before, archivists need to muse about whether the language of finding aids is the same as the language of most of the web browsers and potential audience for, and users of, archival records. And, of course, I do not mean this in any literal sense, questioning whether finding aids should be in English or some other language, but in a metaphorical sense-wondering if a finding aid as traditionally conceived of (from inventories and registers to EAD documents) is anything like what someone on the Web might be expecting.

One wonders what finding aids are trying to tell us? Steven Conn, in explaining museums in the Victorian era, writes of a "metanarrative of evolutionary progress. A trip through the galleries followed a trajectory from simple to complex, from savage to civilized, from ancient to modern ... . Museums functioned as the most widely accessible public form to underscore a positivist, progressive, and hierarchical view of the world, and they gave that view material form and scientific legitimacy." 45 In fact, museum exhibitions have displayed from their beginning an impulse to order and categorize. David Benjamin describes Charles Wilson Peale's museum enterprise in the later eighteenth century in the following way:

Peale's representation of the world was clearly structured, and he intended his audience to extend the economic, social, moral, intellectual, and religious lessons of the museum to their daily lives. He selected the categories of exhibits and he chose the systems by which displays were arranged. His 'world in miniature' situated humans at the top of the natural order. Humanity, too, was ordered. Peale provided exemplars of military, political, and intellectual authority, as well as images of the range of human races, the sick and the well, and the moral and criminal. In gridlike, systematic arrangements of animals and artifacts, hierarchical relationships were made to appear natural. ${ }^{46}$

Many archivists, seeing strict hierarchical structures in their records accumulations, probably convey something similar, although lacking the more 
visual, three-dimensional experiences of galleries. What archivists communicate comes through the texts of their printed or online finding aids or catalogues. Still, beyond the actual words conveyed and organized in these finding aids can be interpreted, and mostly what we find is that records have structure and meaning beyond their most basic or rudimentary level of discourse.

When an archivist sits down at his or her computer to compose the final version of the archival finding aid, what is going on in the archivist's mind? Daniel J. Sherman and Irit Rogoff, in describing the role of the museum, note that the "concept of the museum emerges as a field of interplay between the social histories of collecting, classifying, displaying, entertaining, and legitimating." ${ }^{7}$ Later, they add, the "museum, in other words, while seemingly representing objectively and empirically located contexts for the object it displays, actually participates in the construction of these categories and in the numerous internal shifts and differentiations they are held to contain." 48 Archivists will likely disagree over the extent to which the act of creating a finding aid presupposes or actually constructs a new order of meaning for the described records. Archivists differ over the concepts of how much order already exists in organizational and, certainly, personal recordkeeping regimes. Yet, every archivist has imposed some order on the records under their control, and the very substance of composing the truncated descriptions (apart from the more routine box and file listings) results in a meaning-laden exercise that is, at its most basic, a public relations exercise (one striving to attract researchers).

I am not sure we can go so far as to see the archival finding aid as an artistic venture, although some archivists have certainly sought to add some artistry to their descriptions, seeking to make their finding aids more than directories. Joshua Taylor, in his classic visual arts handbook, believes that "many centuries ago it was recognized that art, in bringing order to the senses, could serve to temper the mind through a reciprocal interplay: the mind imposed order on the sensuous environment, and the senses, thus well ordered, presented the mind with a tangible paradigm of harmonic perfection." 49 I have seen neat and orderly finding aids that bear little similarity to the records jammed in containers or still wrapped in original storage devices such as ribbons and old wrappers. I have also seen apparently orderly finding aids that do not reflect much of an act of creation or even one of rote copying of the records. In neither case have we witnessed an artistic effort, but most archivists would confess to having little in the way of art as an objective. Many archivists would describe 
their processing work as art rather than science, an activity based on their sensibility about what researchers need and their own knowledge of the records being described.

One might wonder why all the fuss about museum classification and exhibition schema, especially since archivists more readily identify with historians than with museum curators. Building on Foucault's concepts about disciplinary knowledge and technologies, Eilean Hooper-Greenwell, considering the emergence of museums, writes:

Through the organization of 'cells,' 'places,' and 'ranks,' the disciplines create complex spaces that are at once architectural, functional, and hierarchical. Spaces fix positions and permit calculations; they mark places and assign values. They individualize things and individuals in a vast table of discrimination and distinction. The division of spaces and bodies entailed the establishment of records: day-books, ledgers, were all required to document the spatial distribution of bodies and things. Thus, in the eighteenth century, the classificatory table became both a technique of power and a procedure of knowledge. ${ }^{50}$

It also reveals that archives have something in common with how museums and libraries classify things. It also suggests a way of reading finding aids.

\section{THE FINDING AID AS AN ARTIFACT OF DESIGN}

Examining finding aids with the same criteria as for what museum curators have done in their work in classifying, organizing, and displaying specimens and artifacts is also to suggest that these archival references are products of design. Donald Norman, one of the widely cited experts on the design of objects and systems, provides a couple of illuminating points about the matter of design relevant to this discussion in his most recent work on design principles. Norman asks, "Why must information be presented in a dull, dreary fashion, such as in a table of numbers? Most of the time we don't need actual numbers, just some indication of whether the trend is up or down, fast or slow, or some rough estimate of the value. So why not display the information in a colorful manner, continually available in the periphery of attention, but in a way that delights rather than distracts?"51 Despite what appears to be continual transformation in 
archival descriptive standards over the past half-century, especially the past two decades, these standards when applied still amount to lots of lists and often unimaginative ways of trying to communicate to researchers what is available in an archives or a particular archival fonds. Designers, like Norman, often look to nature and other sectors for ideas about design. Norman also mentions, for example, "Many natural systems, from the actions of ants and bees, to the flocking of birds, and even the growth of cities and the structure of the stock market, occur as a natural result of the interaction of multiple bodies, not through some central, coordinated control structure." Norman continues by noting that "modern control theory" has evolved from any "assumption of a central command post" to adopt "distributed control" as a "hallmark of today's systems." 52 Is there anything natural in how archivists construct finding aids, except for the millennia old tradition of making lists that date back nearly to the beginning of writing.

Those who write about design generally argue that design can only transpire, at least good design can, if one knows the intended audience or user of the design. This makes sense. Those who write about system's design argue much the same thing. Who are finding aids intended for? Archivists seeking to connect with the public, trying to communicate the importance of archival records to society and to scholars, often have a large gap to transverse. Steven Lubar, writing about museum exhibitions, explains, "one difference between historians and the general public is the extent of critical distance we put between ourselves and our subjects. We share an interest in history, but the approach we take is different. Our sources are also different; historians want to use archives and objects, the public often turns to memory, personal connections, and family stories."53 If this is true for museums, how more true is it for archives? We might try to explain archives as being repositories of memory and containing innumerable stories, and there is a certain relevance to this, but we might also blur the sense of archives into being little more than storehouses of stuff, not unlike what we might find at flea markets and secondhand stores. And do finding aids — as a descriptive device — only provide a kind of false order to these piles of stuff, which have accumulated over time and have little order except as the product of a collecting or hoarding impulse?

Postmodernists and other scholars have seen the archive as a societal metaphor, with particular emphasis on how it orders things. A study of the conscious design of mapping as part of English imperialism provides an example: 
The built environment of the archive and museum has long served as a fundamental metaphor for modern European conceptions of knowledge creation. Data and artifacts can be collected within sturdy walls and there reassembled into meaningful arrangements. Indeed, the walls are overly protective. They physically divorce the collected data and artifacts from the actual contexts of their occurrence and existence. They keep their contents from being harmed and they actively shield them from the confusion and corruption of the world beyond. Within those walls, the archivist or curator constructs an artificial environment within which data and artifacts can be rearranged. ${ }^{54}$

One can see in this both the finding aid as a deliberate paper or electronic means of providing meaningful arrangement and how design, with all its artificial ordering, plays a role in the construction of finding aids as well. This particular scholar also considers the post-structuralist archive, commenting that there is "no longer the coherent and ordered archive as it traditionally has been envisioned: it is fractured, ambiguous, duplicitous, and nuanced. The coherency and order of the archive is an ideological myth."55 And the archival finding aid may be one of the prime means by which to sustain this myth. The archival finding aid might be to records what the university, as Jefferson saw it in his design of The University of Virginia- the "reconciliation" of "regimentation and individual expression, of hierarchical order and relaxed improvising"56 - to human knowledge.

\section{ACCOUNTABILITY AND THE FINDING AID}

Sometimes archivists and records managers see themselves as powerless, at least in a comparative sense, and as a result, are placid in the face of controversies, improprieties, and even illegalities. It is easy to see themselves as so ineffective that they lack any responsibilities to speak up and make themselves heard and more visible. This is ridiculous, of course. As Wendell Berry once put it, "The world is being destroyed, no doubt about it, by the greed of the rich and powerful. It is also being destroyed by popular demand. There are not enough rich and powerful people to consume the whole world; for that, the rich and powerful need the help of countless ordinary people." ${ }^{, 57}$ Are archivists lurking somewhere among these ordinary people and their ordinary products, such as finding aids? 
Archivists, in one of their roles as guardians of accountability, are often invisible, perhaps because they have weak links in being held accountable themselves. For example, archivists have only begun to be incorporated into the structure of the university as faculty. Now, I can hear the moans about how unaccountable faculty generally are, as a chorus of critics has slammed higher education for the past decade or more. James Axtell reminds us that "faculty members are constantly and heavily accountable, less to outside authorities than to the high standards of their own profession," and face criticism through the dissertation process, publishing, reviewers, student evaluators, tenure review committees, and the like. ${ }^{58}$ The archival community has only begun to place members of its clan into the academy, and the persisting weakness of this aspect of the profession certainly has removed one aspect of critical analysis, as well as visibility, of the archival mission and role. We can extrapolate, however, and note that the nature of accountability of archivists in general is weak; since their positions within organizations do not provide them a visible role of authority and influence, they lack enforceable professional standards or codes such as ethics. Further, they are not perceived to be working with essential materials in their organizations given the perceptions of archives as old and dusty records of interest only to a select group of researchers (researchers who themselves often lack any real societal authority). It is not unusual to read in a newspaper an account of some institutional scandal concerning records and information systems and see not a single reference to the archivists who may work in these organizations or to ever hear anything from them about these problems. Archivists may lack the kinds of accountability procedures Axtell is referring to in the academic milieu, or they may look to other places, outside of their own professional associations and networks, for such accountability.

Our society is one that is constantly beset by controversies, over and about nearly anything, so archivists not only need to be prepared for such events but to understand how to prepare finding aids with this in mind. A recent example concerns a human skeleton, now called Kennewick Man, washed out of a bank on the Columbia River in the mid-1990s. David Hurst Thomas believes that the "pivotal issue at Kennewick is not about religion or science. It is about politics. The dispute is about control and power, not philosophy. Who gets to control ancient American history-governmental agencies, the academic community, or modern Indian people?"59 What scholars once took for granted, unearthing a skeleton and studying it at leisure, is now fraught with controversies, debates, and legal contests. Documentation, carefully compiled evidence, takes on a much more important 
role, both the records generated via research and those emanating in the courtroom. And such controversies suggest why the guardians of documentary evidence, in whatever form, need to listen to what is happening in contemporary society. Richard Kurin, in defending the Smithsonian in its actions in the Enola Gay and other controversial exhibitions, argues that:

museum curators have to listen to the voices of the represented not only because of political expediency and goodwill. They should actually try to hear those voices, because there may be something insightful and valuable in the substance of what they actually have to say. ... It does not mean that curators and scholars give up their responsibilities. But it does mean that they fully and honestly and intellectually engage those whom they seek to represent. The presence of those voices should not lead to bad history any more than bad history should be allowed to silence those voices. $^{60}$

Of course, historical records, even though requiring interpretation and analysis, are voices, indeed usually dead voices, needing to be represented as well. Some of the very controversial interpretations are a result of trying to let those voices speak, in many cases voices that had not previously been heard because they had not been declassified, discovered, or dissected. This is the nature of records, that they provide accountability and that accountability brings uneasiness in their frankness.

Why accountability has come to be such a vital concern in our age can be seen in Ursula Franklin's assessment of technological entreprenurialship: "You see, if somebody robs a store, it's a crime and the state is all set and ready to nab the criminal. But if somebody steals from the commons and from the future, it is seen as entrepreneurial activity and the state cheers and gives them the concessions rather than arresting them." ${ }^{\prime \prime}$ In such an environment, the temptations are great and the notion of accountability—-which must be set and defined—-must be both broad and precise enough to hold people and institutions to some sort of higher standard (whether it's moral, ethical, or religious might not matter). The increasing number of government regulations concerning records and information systems and court cases invoking fines and penalties for the willful destruction of evidence all attest to the importance of records as part of a society more attuned to the notion of accountability, even if the 
laws and lawsuits suggest that organizations and individuals are even more determined to make sure that they are not caught up with their records and the evidence in them exposed publicly. Are there any implications for the construction of finding aids in this new era? Will archivists be tempted not to report on their records as openly as they have in the past, or will they simply have fewer and less valuable records to describe in the first place?

One of the reasons why the stakes in accountability has increased in universities, as just one example, is because of the changing relationship between government and other sectors of society. A half-century ago, Jacques Barzun wrote, "though it is clearly impossible, the government expects to buy research and ideas in the same way as it buys soap and chairs." The reason Barzun thought it impossible was because "in the end, success comes only out of a happy conjunction of circumstances; it cannot be bought because they cannot be specified." 62 Now, however, universities have grown much more dependent not only on government but on business as well. This can be seen in the proliferation of university-based, government-funded security studies centers, many teetering uneasily between Pentagon extensions and educational research units more likely to be based in the university. Under circumstances such as this, records must be carefully managed and systems of accountability created and maintained. Archivists creating finding aids must think of their audiences, as well as make sure that they provide full disclosure about the nature of the records, their creation, continuing value, content, and relationship to organizational and societal issues and concerns. Why shouldn't archivists write finding aids to assist the search for records for legal purposes as much as for servicing other researchers? Records managers, considering changing information technologies and laws and regulations governing communication systems such as e-mail, seem to be nearly completely focused on the regulatory and compliance aspects of their work. Are archivists so different than records managers?

Universities, long a place where values such as accountability and ethics have been nurtured, have also lost their way in our crass and confusing era. Derek Bok notes, quite simply and bluntly, that "to keep profit-seeking within reasonable bounds, a university must have a clear sense of the values needed to pursue its goals with a high degree of quality and integrity. When the values become blurred and begin to lose their hold, the urge to make money quickly spreads throughout the institution." ${ }^{\text {"63 }}$ We have all seen this in a variety of ways. No longer is teaching honored, but how much fame a faculty member brings is the foremost concern. Research 
is equated with funding rather than its contribution to knowledge. Compromises in undergraduate and graduate programs are easily and quickly made either if the costs of quality are high or if more profits can be made by focusing on other programs, projects, and prospects. Individuals who are students also join in, becoming more interested in buying a degree rather than in learning anything. The pressures and temptations are so great that the bounds of accountability are loosened and the processes of evaluating, critiquing, and, when necessary, reprimanding people are jettisoned. I mention such contentious matters only because the largest portion of entry-level archivist positions are connected to universities, many located in the university archives, and universities may well be the most documented institution in the United States (if not the world). Have the new academic concerns with accountability, especially to society as the question of the university's traditional claim to be a public good is challenged or revised, extended to the work of archivists in universities? Should they be writing finding aids to help universities locate records to protect them from litigation or to answer difficult queries about their role and functions?

Some worry that the emphasis on open access to government records, in the name of accountability or whatever, leads to fewer and more incomplete documents. Well, that may be. There is another reason. Records need to be accessible in order to counter or support claims made about the government's activities. Noam Chomsky, contentious about every government venture, contends that any topic you pick leads to a skewed version of reality - the "picture of the world that's presented to the public has only the remotest reaction to reality. The truth of the matter is buried under edifice after edifice of lies upon lies." 64 Actually, the truth of the matter is buried under stacks of records, although the continuing philosophical and practical discourses on whether truth is attainable or even desirable certainly make the matter more complicated. What these issues suggest is to make us speculate about what archivists are thinking when they strive to write finding aids. Are these finding aids intended to enable researchers and the public peer under the stacks of records and to see past the secrecy, firewalls, and screens to enable anyone to understand what an organization, government, university, or an individual was doing at some particular moment or in some crucial event? Will finding aids be read at some point in the future as just more documents needing to be deconstructed in order to get at their true meaning or as just another bureaucratic or technocratic interpretation of reality? 


\section{CONCLUSION}

Elizabeth Yakel, in part of a series of provocative research articles she has written about archival use and representation, had this to say about the role of the archival finding aid:

It is in finding aids that users' representations of archives meet archivists' representations of collections. If these two cognitive representations intersect enough, the user is able to locate and utilize the archives and to identify primary sources that may hold the answer to his or her inquiry. If these representations diverge, the access tools are useless for the researcher. Creating finding aids that are true boundary objects is key. ${ }^{65}$

I would argue that we are still a very far distance from seeing these representations come together, at least in terms of the scholarly users of archives. Likewise, Jean-Stéphen Piché suggests how the technology of the Web could enable us to link information from different archival functions (knocking down the internal barriers we create) seamlessly in a way that could benefit researchers and lead to very different kinds of finding aids. Piché contends that the "objective for archives should be to use Internet WWW-related technologies to make archivists' already deep, but often sadly disjointed, knowledge about the context and content of the records available and represented in the infrastructure of internal and external websites of archival institutions." ${ }^{\prime \prime 6}$ Reconsidering such boundaries, which often become barriers, can be done by trying to imagine how scholars and social commentators might look at the archival finding aid on its own merits, as a representation not just of the records by the archivist but also of the archivist and the archives profession.

While the richness of the recent new scholarship about the meaning of the notion of the archive or the function of archiving has both broadened and deepened, ${ }^{67}$ mostly the practice of representing archives has been remarkably sterile except for the work, often innovative, on standards and methodologies. Archivists have generally been fixated with the generation of descriptive standards and rather mundane finding aids building on these standards (at least on the ground in common practice and application), despite continuing evidence about the inconsistent use of these devices by researchers, without much of a nod toward the interesting dialogue about the roles and values of archival materials, the nuances of the evidence provided by these sources, or any assessment of a societal mission that 
encompasses anything broader than providing the raw materials of history. In one major analysis of how Canadian historians use archival materials, the authors write of the "notion of trust, of a trusted professional who provides a service, and of trustworthiness, especially of the records and other types of historical sources...." They note that this "bond of trust is established, in part, by the methods that archivists use in discharging their responsibilities over time. These include deploying the critical and research skills that they share with historians, to which are added knowledge and skill in appraisal, description of sources, exhibition design, reference services, and records management." ${ }^{68}$ We might surmise that such trust should also rest, at least partly, on understanding how society and scholars perceive archives. This Canadian study suggests that these historians value highly archival finding aids as a research tool, but then again, this is not a study about how these guides are really used.

Interpreting, controlling, publicizing, digging through sedimentary layers, transforming records by describing, speaking, artistic expression, designing, accounting, promoting the public good, and building trust-it is not often that archivists discuss such matters when they engage in preparing finding aids or reconsider the fine points of such work. They should talk more like this, if only to try to place their finding aids in a different light.

We live in a world with expectations for instant and easy access, but there is often a price to be paid for this. Matthew Fuller, a few years ago, put it very simply: "The search engine is absolutely unable to treat a word or any collection of symbols entered into it in a contextualized manner." 69 Maybe this is changing, but the point is that there are limitations to seeing archival records as matter mainly to be placed in conceptual containers in order for their contents to be quickly searched and harvested. When we think like this, we begin to lose sight of some of the most salient characteristics of an archival record. Sometimes the concentration of energy on descriptive standardization, while certainly important, robs us of the beauty and significance of the documentary record.

Let's put it another way. Poet Luci Shaw writes that the "word story is linked with the word history (from the Greek word historia), the learning that comes from poema, a word that reflects the idea of something being made." ${ }^{70}$ And it is really the art of storytelling perhaps that archivists need to be concerned with, as Shaw suggests: "Every time we tell a story or write a poem or compose an essay we give chaos a way of re-integrating back into order; we reverse entropy; pattern and meaning begin to overcome randomness and decay. We find satisfaction in juxtaposition and linkage and succession and resolution as things split and differentiate and flow 
together again."71 So, we need a kind of poetics in archival description, or we risk losing what our larger mission is about, as well as something of the joy of our work. As English columnist Michael Bywater writes, "Despite the obsession of our species with organizing, categorizing, and making lists ... we have not managed to organize our thinking about loss." "72 Or in other words, we lose sight of the big picture. When we represent archives, we also represent what has not been saved, the individual archivist's own interest in preserving something of the past, the objectives of the original creators of documents, and society's own sense and value of history.

\section{NOTES}

1. See, for example, Christopher J. Prom, "The EAD Cookbook: A Survey and Usability Study," American Archivist 65 (Fall/Winter 2002): 257-275.

2. Helen R. Tibbo, "Primarily History in America: How U.S. Historians Search for Primary Materials at the Dawn of the Digital Age," American Archivist 66 (Spring/Summer 2003): 10. Similarly, Elizabeth Yakel—in her "Thinking Inside and Outside the Boxes: Archival Reference Services at the Turn of the Century," Archivaria 49 (2000): 140-160 - suggests that archivists need to embrace knowledge management approaches enabling them to take advantage of the networked environment in order to empower archivists with their researchers in a way for generating new knowledge about their holdings and the retrieval of information and evidence from them.

3. See, for example, Ian G. Anderson, "Are You Being Served? Historians and the Search for Primary Sources," Archivaria 58 (Fall 2004): 81-129.

4. Wendy Duff and Penka Stoyanova, "Transforming the Crazy Quilt: Archival Displays from a Users' Point of View," Archivaria 45 (Spring 1998): 44-79.

5. Wendy M. Duff and Catherine A. Johnson, "Where Is the List with All the Names? Information-Seeking Behavior of Genealogists," American Archivist 66 (Spring/Summer 2003): 79-95. Indeed, we have known this for a long time, as just the little amount of research about the implications of placing archival descriptions into library bibliographic databases suggests that archivists need to rethink their notion of what they knew about how researchers used archives; see Avra Michelson's "Description and Reference in the Age of Automation," American Archivist 50 (Spring 1987): 192-208.

6. Wendy M. Duff and Catherine A. Johnson, "A Virtual Expression of Need: An Analysis of E-Mail Reference Questions," American Archivist 64 (Spring/Summer 2001): 44.

7. See, for example, Jennifer A. Marshall, "The Impact of EAD Adoption on Archival Programs: A Pilot Survey of Early Implementers," Journal of Archival Organization 1, no. 1 (2002): 35-55.

8. See Victoria Lemieux, "RADical Surgery: A Case Study in Using RAD to Produce a Thematic Guide," Archivaria 39 (Spring 1995): 51-69, describing an effort to create a guide that works for genealogists. 
9. Elaine G. Toms and Wendy Duff, "I spent 1 1/2 hours sifting through one large box. . . .': Diaries as Information Behavior of the Archives Users; Lessons Learned," Journal of the American Society for Information Science and Technology 53 (December 2002): 1232-1238.

10. Elizabeth Yakel and Deborah A. Torres, "AI: Archival Intelligence and User Expertise," American Archivist 66 (Spring/Summer 2003): 51-78.

11. Tibbo, "Primarily History in America," 28.

12. Ibid., 29.

13. Wendy M. Duff and Catherine A. Johnson, "Accidentally Found on Purpose: Information-Seeking Behavior of Historians in Archives," Library Quarterly 72, no. 4 (2002): 472.

14. Michelle Light and Tom Hyry, "Colophons and Annotations: New Directions for the Finding Aid," American Archivist 65 (Fall/Winter 2002): 216.

15. Ibid., 217.

16. Ibid., 218.

17. Helen R. Tibbo and Lokman I. Meho, "Finding Finding Aids on the World Wide Web," American Archivist 64 (Spring/Summer 2001): 61-77.

18. Daniel V. Pitti, "Encoded Archival Description: The Development of an Encoding Standard for Archival Finding Aids," American Archivist 60 (Summer 1997): 268-283 (quotation, p. 272).

19. For an early assessment of such issues, see Helen R. Tibbo, "Interviewing Techniques for Remote Reference: Electronic Versus Traditional Environments," American Archivist 58 (Summer 1995): 294-310.

20. Clay Redding, for example, has indicated that archivists in using EAD had become more focused on the presentational qualities than in standardizing content so that information interchange can be achieved. See his "Reengineering Finding Aids Revisited: Current Archival Descriptive Practice and Its Effect on EAD Implementation," Journal of Archival Organization 1, no. 3 (2002): 35-50.

21. Lawrence Dowler, "The Role of Use in Defining Archival Practice and Principles: A Research Agenda for the Availability and Use of Records," American Archivist 51 (Winter and Spring 1988): 74-86.

22. A variety of miscellaneous and quite divergent archival user studies began to appear by the early 1980s and early 1990s, such as Clark A. Elliott, "Citation Patterns and Documentation for the History of Science: Some Methodological Considerations," American Archivist 44 (Spring 1981): 131-142; Fredric Miller, "Use, Appraisal, and Research: A Case Study of Social History," American Archivist 49 (Fall 1986): 371392; Paul Conway, "Research in Presidential Libraries: A User Survey," Midwestern Archivist 11, no. 1 (1986): 35-56; Jacqueline Goggin, “The Indirect Approach: A Study of Scholarly Users of Black and Women's Organizational Records in the Library of Congress Manuscript Division," Midwestern Archivist 11, no. 1 (1986): 57-67; Diane L. Beattie, "An Archival User Study: Researchers in the Field of Women's History," Archivaria 29 (Winter 1989-1990): 33-50; and Barbara C. Orbach, "The View From the Researcher's Desk: Historians' Perceptions of Research and Repositories,' American Archivist 54 (Winter 1991): 28- 43. Many of these studies played off from Paul Conway, "Facts and Frameworks: An Approach to Studying the Users of Archives," American Archivist 49 (Fall 1986): 393-407 and earlier or contemporary expressions of concern about a lack of understanding about archival users, such as Richard H. 
Lytle, "Intellectual Access to Archives: I. Provenance and Content Indexing Methods of Subject Retrieval," American Archivist 43 (Winter 1980): 64-75 and "II. Report of an Experiment Comparing Provenance and Content Indexing Methods of Subject Retrieval," American Archivist 43 (Spring 1980): 191-207; Mary Jo Pugh, "The Illusion of Omniscience: Subject Access and the Reference Archivist," American Archivist 45 (Winter 1982): 33-44; Elsie Y. Freeman, "In the Eye of the Beholder: Archives Administration from the User's Point of View," American Archivist 47 (Spring 1984): 111-123; William J. Maher, "The Use of User Studies," Midwestern Archivist 11, no. 1 (1986): 15-26; Roy C. Turnbaugh, "Archival Mission and User Studies," Midwestern Archivist 11, no. 1 (1986): 27-33, a study focusing on the limitations of user studies for planning for programs, as well as the limitations of generating new finding aids to attract new researchers; Bruce W. Dearstyne, "What Is the Use of Archives? A Challenge for the Profession," American Archivist 50 (Winter 1987): 76-87; and Richard J. Cox, "Archivists and the Use of Archival Records; Or, A View from the World of Documentary Editing," Provenance 9 (Spring/Fall 1991): 89-110; and Richard J. Cox, "Researching Archival Reference as an Information Function: Observations on Needs and Opportunities, $R Q 31$ (Spring 1992): 387-397.

23. Goggin, "The Indirect Approach," 57.

24. There has been a burst of new research on archival users generated by Wendy Duff, Helen Tibbo, and Beth Yakel who in their academic posts have made this an important part of their research agendas. The references in this essay include many to these three intrepid researchers. We are also seeing the published results of their students' work as well, such as Kristin E. Martin, "Analysis of Remote Reference Correspondence at a Large Academic Manuscripts Collection," American Archivist 64 (Spring/Summer 2001): 17-42.

25. Dennis Meissner, "First Things First: Reengineering Finding Aids for Implementation of EAD," American Archivist 60 (Fall 1997): 375.

26. Christopher J. Prom, "User Interactions with Electronic Finding Aids in a Controlled Setting," American Archivist 67 (Fall/Winter 2004): 234.

27. Ibid., 263.

28. Ibid., 265.

29. See, for example, Elizabeth Yakel and Laura L. Bost, "Understanding Administrative Use and Users in University Archives," American Archivist 57 (Fall 1994): 596-615.

30. William C. Binkley, "A Historian Looks at The National Union Catalog of Manuscript Collections," American Archivist 28 (July 1965): 407.

31. See, for example, Robert P. Spindler and Richard Pearce-Moses, "Does AMC Mean 'Archives Made Confusing'? Patron Understanding of USMARC AMC Cataloguing Records," American Archivist 56 (Spring 1993): 330-347.

32. Mary Jo Pugh, "The Illusion of Omniscience: Subject Access and the Reference Archivist," American Archivist 45 (Winter 1982): 42.

33. David Bearman, "Archives and Manuscripts Control with Bibliographic Utilities: Challenges and Opportunities," American Archivist 52 (Winter 1989): 39.

34. Elizabeth Yakel, "Listening to Users," Archival Issues 26, no. 2 (2002): 117.

35. Ibid., 118.

36. Ibid., p. 122. 
37. See, for example, Elizabeth Diamond, "The Archivist as Forensic Scientist Seeing Ourselves in a Different Way," Archivaria 38 (Fall 1994): 139-154. At one point, Diamond notes how archivists are often frustrated in "dealing with researchers who do not read the introduction to finding aids before they start to search. She suggests this is because they want "instant access and are frequently too impatient to realize that they also need the contextual background" (p. 143). While I certainly don't want to downplay the importance of contextual information for archival research, I do believe that the lack use of finding aids may suggest other more profound problems with archivists and their assumptions about how researchers work or should work.

38. Ann Pederson, "Unlocking Hidden Treasures Through Description: Comments on Archival Voyages of Discovery," Archivaria 37 (Spring 1994): 51.

39. Steven C. Dubin, Displays of Power: Controversy in the American Museum from the Enola Gay to Sensation! New York: New York University Press, 2001, 5.

40. Kevin Walsh, The Representation of the Past: Museum and Heritage in the Post-Modern World. London: Routledge, 1992, 31-33.

41. Chon A. Noriega, "On Museum Row: Aesthetics and the Politics of Exhibition," Daedalus 128 (Summer 1999): 64.

42. Paul Collins, Sixpence House: Lost in a Town of Books. New York: Bloomsbury, 2003, 205-206.

43. Charles Merewether, "Traces of Loss," in Michael S. Roth with Claire Lyons and Charles Merewether, Irresistible Decay: Ruins Reclaimed Los Angeles: Getty Research Institute for the History of Art and the Humanities, 1997, 25.

44. Miguel Tamen, Friends of Interpretable Objects. Cambridge: Harvard University Press, 2001, 117.

45. Steven Conn, Museums and American Intellectual Life, 1876-1926. Chicago: University of Chicago Press, 1998, 5.

46. David R. Benjamin, Public Culture in the Early Republic: Peale's Museum and Its Audience. Washington, DC: Smithsonian Institution Press, 1995. 145.

47. Daniel J. Sherman and Irit Rogoff, eds., Museum Culture: Histories, Discourses, Spectacles. Minneapolis: University of Minnesota Press, 1994, x.

48. Ibid., xi.

49. Joshua C. Taylor, Learning to Look: A Handbook for the Visual Arts, 2nd ed. Chicago: University of Chicago Press, 1981, p. 150.

50. Eilean Hooper-Greenwell, Museums and the Shaping of Knowledge. London: Routledge, 1992, 170.

51. Donald A. Norman, Emotional Design: Why We Love (or Hate) Everyday Things. New York: Basic Books, 2004, 101.

52. Ibid., 202.

53. Steven Lubar, "Exhibiting Memories," in Amy Henderson and Adrienne L. Kaeppler, eds., Exhibiting Dilemmas: Issues of Representation at the Smithsonian. Washington, DC: Smithsonian Institution Press, 1999, 16.

54. Matthew H. Edney, Mapping an Empire: The Geographical Construction of British India, 1765-1843. Chicago: University of Chicago Press, 1999, 39.

55. Ibid., p. 41.

56. Garry Wills, Mr. Jefferson's University. New York: National Geographic, 2002, 17. 
57. Wendell Berry, Sex, Economy, Freedom, and Community: Eight Essays. New York: Pantheon Books, 1993, 32.

58. James Axtell, "What's Wrong - and Right - with American Higher Education?" Virginia Quarterly Review 79 (Spring 2003): 189-208 (quotation p. 203).

59. David Hurst Thomas, Skull Wars: Kennewick Man, Archaeology, and the Battle for Native American Identity. New York: Basic Books, 2000, xxv.

60. Richard Kurin, Reflections of a Culture Broker: A View from the Smithsonian Washington, DC. Smithsonian Institution Press, 1997, 77.

61. Ursula Franklin, The Real World of Technology. (Toronto: House of Anansi Press, 1998, 123.

62. Jacques Barzun, House of Intellect New York: Harper Perennial Modern Classics, 2002, 212, 213.

63. Derek Bok, Universities in the Marketplace: The Commercialism of Higher Education. Princeton, NJ: Princeton University Press, 2003, 6.

64. Noam Chomsky, Media Control: The Spectacular Achievements of Propaganda, 2nd ed., (orig. pub. 1991) in Open Media Collection: 9-11, Media Control, Acts of Aggression. New York: Quality Paperback Book Club, 2003, 37.

65. Elizabeth Yakel, "Listening to Users," Archival Issues 26, no. 2 (2002): 122.

66. Jean-Stéphen Piché, "Doing What's Possible with What We've Got: Using the World Wide Web to Integrate Archival Functions," American Archivist 61 (Spring 1998): 120.

67. This literature is growing so rapidly that it would be challenging to capture its nature in an explanatory footnote that is not longer than the text of this essay. However, one can get a sense of the nature of this scholarship by perusing Francis X. Blouin Jr. and William G. Rosenberg, eds., Archives, Documentation, and Institutions of Social Memory: Essays from the Sawyer Seminar. Ann Arbor: University of Michigan Press, 2006.

68. Wendy Duff, Barbara Craig, and Joan Cherry, "Finding and Using Archival Resources: A Cross-Canada Survey of Historians Studying Canadian History," Archivaria 58 (Fall 2004): 54.

69. Matthew Fuller, Behind the Blip: Essays on the Culture of Software. Brooklyn, NY: Autonomedia, 2003, 71.

70. Luci Shaw, in Jennifer Holberg, ed., Shouts and Whispers: Twenty-one Writers Speak About Their Writing and Their Faith. Grand Rapids, MI: William B. Eerdmans Pub. Co., 2006, 203.

71. Ibid., p. 205.

72. Michael Bywater, Lost Worlds: What Have We Lost, \& Where Did It Go? London: Granta Books, 2004, 3. 